\title{
Азербайджано-северо-кавказские связи на примере Чечни в советский и постсоветский период
}

$\mathrm{A}$ зербайджано-чеченские исторические связи уходят в глубь веков, но в советское и особенно постсоветское время они приобрели новые очертания. В советское время политические и хозяйственные связи между народами Азербайджана и Северного Кавказа приобрели новые очертания. Но условия военного времени, спад производственной деятельности и торговли, разруха и другие обстоятельства не могли не сказаться на их характере. Изменение социально-политического строя и управления, деятельность новых органов исполнительной власти не вызывало доверия у населения.

В октябре 1917 года советское руководство основало Народный комиссариат по делам национальностей (Наркомнац) во главе со Сталиным. Мусульманскую секцию Нарконаца возглавлял Мирсаит Султан Галлиев. В январе 1918 года при Наркомнаце был создан Мусульманский комиссариат (Муском), а также местные мусульманские комиссариаты. В ноябре 1918 года возникло Центральное бюро мусульманкоммунистов, а в 1919 году - мусульманские секции РКП(б).

Многие посулы большевиков оказались декларативными, а различные “форсированные меры” по проведению коллективизации, изменению системы образования, преследование духовенства, верующих, запрещение шариатских судов, и т.д. - вызывали недовольство на местах. Массовые политические выступления на Кавказе с установлением советской власти не только не закончились, но развернулись с новой силой.

11-16 февраля 1930 года на совещании при ЦК состоялось по вопросам коллективизации и ликвидации кулачества как класса было принято постановление от 20 февраля 1930 года “О коллективизации и борьбе с кулачеством в национальных, экономически отсталых районах”. Население, выражавшее недовольство на религиозной почве, неудовлетворенное аграрной политикой и образом правления, а также классифицированное как кулаки, после этого постановления подверглось еще большим репрессиям. Это не могло не вызвать ответной реакции со стороны кавказских народов.

Одно из крупных вооруженных выступлений произошло в Чечне в сел. Шали и Гойты под руководством бывшего военного министра Северо-Кавказского эмиратства Щиты Истамулова. Оно нашло отклик в Дагестане, особенно в Аварском, Андийском и Хасавюртовском округах, а также в Казбековском подрайоне. Подозревались их связи с 
бывшим главой Горской Республики А.-М. Чермоевым и бывшим офицерством, сгруппированным в горах Чечни и Ингушетии. В Нагорном Дагестане шариатские советы приняли решение о борьбе с советской властью. Повстанческое движение охватило некоторые районы Чечни и Дагестана. Наиболее сильным было выступление дидоевцев, которых поддерживали ингушские и грузинские повстанцы. После этого появились сообщения об аналогичных выступлениях в Закатальском округе Азербайджана. Так, в Алибацком и Гахском районах, в городе Шеки с новой силой заявили о себе антисоветские настроения, начались формирования ополченцев. В Гянджинском округе развернулась деятельность повстанческого отряда Мамед Касума. В Гахском районе восставшие заняли Верхний и Нижний Гейнюк, селения Балаханы и Кирчак, а также селения по дороге Шеки, Закаталы. Они действовали под лозунгами: “Освобождение народа из-под власти Советов”, “Долой колхозы”. Органы ГПУ докладывали в Москву о руководстве восставшими в Азербайджане из Дагестана и турками. Советская администрация направила на подавление восставших районов Азербайджана и Дагестана воинские части. Были перекрыты проходы из Дагестана в Закаталы, чтобы не допустить прорыва повстанцев в Азербайджан. ${ }^{145}$

В тот период фиксируется массовый выход местных жителей из колхозов, антисоветские выступления.

В марте 1932 года крупное восстание под началом Имама Муцу Шамилева, Усмана Ушхаева, Истамулова и Дады Кебетова вспыхнуло в Ножай-Юртовском районе Чечни. В 1934 году выступления против советской власти еще более активизировались. 146

На основании постановления СНК СССР от 21 мая 1936 года, № 911 "О переселении 1000 кулацких хозяйств из Дагестана и Чечено-Ингушской области” тысячи человек были высланы в Киргизскую ССР. Более того, в 1940-е годы 13 народностей СССР подверглись репрессиям по обвинению в пособничестве фашистам и 3,2 млн. человек были насильно депортированы якобы из-за участия в повстанческой организации “Особая партия Кавказских братьев” (ОПКБ) с целью свержения большевиков.

В СССР работал механизм беспощадной репрессии - карательных мер, применяемых государственными органами под предлогом защиты и сохранения существующего строя. Все эти мероприятия партии и советского правительства позже вошли в историю под названием сталинские репрессии, массовые репрессии, массовый террор, и стали составной и сопутствующей частью формирования и утверждение тоталитарного режима советского государства.

Цель всех этих репрессий - уничтожение потенциальных и активных противников, а также устрашение народа. Во главе советского режима стоял единоличный лидер - И. Сталин, который принял на себя принятие всех важнейших решений, что привело к утверждению его культа личности. По оценке некоторых экспертов нельзя всю вину возлагать на одного Сталина, виной всему является сама доктрина большевизма. Однако нужно признать, что и до Сталина, и после него

\footnotetext{
${ }^{145}$ Коллективизаиия и антиколхозные выступления в Дагестане (1927 - 1940). Документы и материалы. Махачкала 2007, с. 46-49, 140-141, 154-155, 158, 164-167.

${ }^{146}$ Коллективизация... с. 170-175, 180-182; 194, 196 - 198, 203.
} 
советское государство не знало таких репрессий и столь жестокого обращения с гражданами. Отметим также, что, поскольку сталинское видение путей эволюции советской государственности было в основе мероприятий того времени, его личное отношение к отдельным народам в значительной степени повлияло на принятие в отношении некоторых из них самых суровых решений.

Репрессии коснулись всех слоев населения, возникали невероятные дела против тех, кто подозревался в приверженности национальному мышлению, а не советским штампам. Шли массовые разоблачения «врагов народа», «вредителей», «шпионов», что отражалось на судьбе не только самих «виновников», но и их родных, близких, коллег. По мнению специалистов, репрессии служили не только как средство наказания или метод устрашения, не только как инструмент устранения реальных и потенциальных противников тоталитарного режима, но и для физического уничтожения реальных конкурентов Сталина. Именно так это и произошло в 1934 году в случае с убийством С.М. Кирова. 10 июля 1934 года в рамках реорганизации спецслужб был создан народный комиссариат внутренних дел СССР (НКВД). В ноябре 1934 года был создан специальный отдел под названием «Особое совещание». Этот отдел получал широкие полномочия по борьбе с врагами народа. Сталин обратился к членам партии с заявлением о необходимости окончательного истребления всех врагов народа. В уголовный кодекс СССР были внесены изменения, согласно которым все дела по политическим заключенным могли рассматриваться в ускоренном порядке без адвокатов и прокуроров в течение 10 дней. В результате в СССР был установлен режим беспредельной власти Сталина. Созданный партийно-государственный аппарат вмешивался в решение всех экономических вопросов. Насильно осуществлялось отчуждение людей от собственности и от вмешательства в дела власти.

Фактически репрессии в СССР никогда и не прекращались. Они начались с момента образования этого государства и завершились его падением. Менялся лишь характер, степень жестокости репрессий. Эпоха 1937-1938 годов, безусловно, стала их кульминацией. К репрессиям можно отнести борьбу с кулачеством, инакомыслием и диссидентством, депортацию народов и т.д. Советская идеология всегда воспитывала советских граждан в духе борьбы. Даже большинство работ по советскому периоду всегда начинались этим словом - «борьба». «Борьба с врагами народа» была той центральной идеей, которая должна была подстегнуть и мобилизовать граждан накануне новых испытаний. Как и все в СССР, репрессии проводились на плановой основе. Планы по численности граждан, которые подлежали аресту, спускались сверху и беспрекословно выполнялись нижестоящими карательными органами.

Что же касается обвинений, то их выбор, по сути, был предопределен и предельно незамысловат.

По обвинению в пособничестве фашистам были репрессированы и изгнаны с мест своего проживания многие народы Кавказа, в том числе чеченцы и ингуши, несмотря на то, что показали небывалый героизм на фронтах второй мировой войны в борьбе против фашизма. Было депортировано около полумиллиона ингушей и чеченцев. По постановлению от 22 марта 1944 года Чечено-Ингушская автономная область была расформирована и образована Грозненская область. Часть Чечено- 
Ингушской АО была разделена между Осетией, Грузией и Дагестаном. Грозненская область активно заселялась переселенцами из других районов страны.

ЧИАССР была восстановлена в 1957 г., но Пригородный район, включенный в состав Северной Осетии, не был возвращен, и проблема эта не решена по сей день.

Автономная республика Ингушетия была создана Указом Президента РФ от 4 июня 1992 года. ${ }^{147}$ Кроме того, в 1990-е годы осетинские беженцы из Южной Осетии, вынужденные перебраться к своим сородичам в Пригородный район, накалили и без того острый этнический конфликт между осетинами и ингушами и вновь вынудили ингушей стать беженцами. ${ }^{148}$

Из-за осетино-ингушского конфликта, вспыхнувшего из-за территории Пригородного района, входящего ныне в состав Северной Осетии, а официально с 1922 по 1944 годы в состав Ингушской АО, а затем ЧИАССР, в Азербайджане появились осетинские переселенцы. В настоящее время в Азербайджане проживает несколько сот осетин, по словам которых в родной Осетии нет работы, и они со своими семьями предпочитают жить в Баку.

Жертвой сталинских репрессий стали не только люди, пострадавшие физически, брошенные в застенки, казненные, либо погибшие в лагерях. Жертвой политических репрессий можно по праву называть весь советский народ, который подвергался психическому и моральному давлению.

Азербайджанский народ не был репрессирован, как многие другие народы Кавказа, по обвинению в пособничестве фашистам. Однако в Азербайджане было осуществлено массовое переселение населения из пограничной полосы. Из приграничных районов с Ираном были выселены все «политически сомнительные элементы». Наряду с этим, жители приграничной полосы подвергались тщательному контролю. К концу войны, в преддверии вполне возможной войны с Турцией, в регионе начался новый виток репрессивной активности в отношении кавказского и тюркского населения, особенно расселенного вдоль побережья Черного моря, вдоль советскотурецкой границы.

Репрессии в СССР продолжались до 1953 года.

В 1948-1953 годы по Постановлению «О переселении колхозников и другого азербайджанского населения из Армянской ССР в Кура-Араксинскую низменность Азербайджанской ССР» депортации из родных очагов подверглись сотни тысяч азербайджанцев Западного Азербайджана. Все это мотивировалось потенциальной возможностью сочувствия мусульманского населения приграничных с Турцией районов. Фактически это означало, что советское руководство не доверяло мусульманскому населению Кавказа, видело в нем врага, «пятую колонну». Такое преувеличенно настороженное отношение, на наш взгляд, трудно оправдать или объяснить. Лишь с конца 1950-х годов большинство репрессированных народов

\footnotetext{
${ }_{147}$ Осенью 1991 года Чечня провозглашается независимой республикой Ичкерией

148 В.А. Авксентьев, Этническая конфликтология. Ч.2. Ставрополь 1996, с.90-91; В.С. Белозеров, Этническая карта Северного Кавказа, Москва 2005, с. 142; Романов Д., Финк Ю. Потенциальные очаги этнических конфликтов на Северном Кавказе (по материалам СМИ), Этнические процессы современности, Ставрополь 1996, с. 47-48; Д.Б. Малышева, Пределы влияния России в Закавказье, Южный фланг СНГ. Центральная Азия - Каспий - Кавказ: энергетика и политика, Москва 2006, с. 296 316.
} 
получили разрешение на возвращение в родные места. Декларация Верховного Совета ССР о признании незаконными всех направленных против них актов была принята 14 ноября 1989 года. Постановление об отмене всех юридических актов, направленных против репрессированных народов было подписано 7 марта, а 26 апреля 1991 года был принят Закон РФ «О реабилитации репрессированных народов».

Историческая справедливость была восстановлена, однако депортация целых народов на основе надуманных обвинений оставила тяжелый след в исторической памяти народов. Длительная задержка с реабилитацией способствовала консервации конфликтного потенциала проблемы. ${ }^{149}$ Следует учитывать и то, что реабилитированные народы возвратились на территорию, уже занятую представителями других этносов. Сложившееся в царское и советское время компактное и чересполосное расселение стало основой недовольства административным и территориальным делением границ Ингушетии, Осетии, Чечни, Карачаево-Черкесии, Кабардино-Балкарии, Ставропольского края и др., при определении государственной границы между Азербайджаном и РФ, Грузией и РФ.

Сталинские репрессии были направлены на борьбу не только против тех, кто сопротивлялся советской власти, подозревался в инакомыслии, но и против предполагаемых, воображаемых врагов режима. В разное время массовым политическим репрессиям подверглись различные слои общества, но в годы Великой Отечественной войны от них пострадали целые народы. Чеченский народ испил эту горькую чашу до дна.

Сталинские репрессии стали подлинной трагедией для всего советского народа, но на Кавказе их последствия ощущаются до сих пор. Неизгладима память о миллионах выселенных, погибших, изувеченных судьбах. Кроме того, репрессии и депортации, перекраивание административно-территориальных единиц на Кавказе заложили основу этнотерриториальных споров и конфликтов, оставили горькую память, сформировали отношения противопоставления «свои-чужие» - «кавказцы-русские». В целом, в сталинский период советской истории многие преступления, правонарушения, неосторожные высказывания и т.д. рассматривались с точки зрения угрозы советскому строю. Репрессиям подвергались по классовому признаку или подозрению в «собственничестве», принадлежности к эксплуататорским классам. Поэтому репрессии в это время в основном носили политический характер.

Репрессии носили антинародный характер и были направлены на уничтожение мусульманских народов с целью передать их землю соседним республикам или другим народам. Самым большим результатом репрессий 1930-х годов стал страх, выработанный у населения перед властью и органами безопасности.

В советское время взаимоотношения и между азербайджанским и чеченским народами протекали в рамках советского государства, происходило взаимообогащение культур, устанавливались культурные связи и пр. По переписи 1989 года в Азербайджанской ССР проживало 456 чеченцев. В советских условиях языком межнационального общения стал русский язык. Развитие транспортных артерий,

149 Эльдар Исмаилов, Власть и народ. Послевоенный сталинизм в Азербайджане, Баку: Изд-во Адильоглу 2003, с. 295-297. 
экономических связей также внесло динамику и интенсивность в общение и взаимосвязи, в частности между азербайджанцами и чеченцами.

Сложные перипетии последних 30 лет: распад СССР, образование независимых государств на Южной Кавказе, две войны в Чечне, этнические конфликты на Северном Кавказе, армяно-азербайджанский нагорно-карабахский конфликт, оккупация армянскими агрессорами $20 \%$ территории Азербайджанской Республики, - не помешали сохранению и упрочению дружественных, добрососедских отношений между народами Азербайджана и Северного Кавказа. В настоящее время руководство Азербайджанской Республики поддерживает равновесие и развивает самые позитивные отношения с республиками и областями Северокавказского региона.

Азербайджанцы и чеченцы, пережившие одинаковые трудности: борьба за независимость, война на своей собственной территории, беженцы, разруха, давление внешних политических сил, нефтяная карта, - всегда сочувственно и понимающе относились друг к другу. Немаловажную роль играл в этом также религиозный фактор, азербайджанцы и чеченцы исповедуют ислам, роль которого после провозглашения «перестройки» и «Гласности» существенно возросла, приобретя политическую значимость и вернув главную позицию в идентификации этих народов.

Во время войны в Чечне в 1994 году в Азербайджан хлынул первый поток беженцев. В Азербайджане они чувствовали себя в безопасности. При этом, беженцы стремились устроить свою жизнь в Баку, найти работу, получить образование, добиться местной прописки. К этому их вынуждали обострение межнациональных отношений на Северном Кавказе, военная напряженность, начало которой было положено двумя чеченскими войнами, тяжести социально-экономического плана: спад производства, безработица, а также ущемление прав или невозможность реализоваться на своей исторической родине. Специально была открыта чеченская школа, различные комитеты, созданные для работы с ними, с 1995 года действовало постпредставительство Ичкерии и др. организации. В 1995 году в городе Баку был открыт Культурный центр Чеченской Республики Ичкерия (январь 1995 - октябрь 2002). Президент Азербайджана Гейдар Алиев политическую проблему Чечни рассматривал как внутреннее дело России, а чеченский вопрос - как гуманитарную проблему. ${ }^{150}$

В Баку неоднократно бывали Зелимхан Яндарбиев, Аслан Масхадов и Мовлади Удугов, которых принимали на самом высоком уровне.

Во время рабочего визита Президента Азербайджанской Республики Гейдара Алиева в Российскую Федерацию 17-18 ноября 1994 года на встрече с ПремьерМинистром Российской Федерации Виктором Чердомырдиным Президент Азербайджанской Республики обратился к нему с просьбой быстрее подписать подготовленный проект об открытии путей сообщения с Россией. А министр обороны Российской Федерации Игорь Родионов проинформировал о ситуации в Чечне. Через

150 Севиндж Алиева, Cmapble $u$ новые 
Чечню проходили железнодорожные и автомобильные пути, закрытие которых были связано со сложившейся там ситуацией. ${ }^{151}$

На встрече с министром внутренних дел России Анатолием Куликовым Президент Азербайджанской Республики Гейдар Алиев подчеркнул, что все события в Чечне, которые происходили с 1994 года, наносили огромный ущерб экономике Азербайджана - были закрыты дороги, коммуникации. Президент Азербайджанской Республики Гейдар Алиев информировал главу Российского государства о сложной ситуации, возникшей в результате закрытия Северокавказской железной дороги и отрицательно влияющей на развитие экономических отношений между Азербайджаном и Россией, в т.ч. обеспечения населения Азербайджана хлебопродуктами. Президент Российской Федерации Борис Ельцин, в свою очередь, заявил о том, что внимательно относится к этим проблемам, и обещал принять самые решительные меры для их решения, дать соответствующие указания Правительству Российской Федерации о восстановлении железнодорожного сообщения, поставке хлебопродуктов, а также по широкому кругу вопросов экономической интеграции двух государств. ${ }^{152}$

После 1994 года в Азербайджане насчитывалось 4,7 тыс. чеченских беженцев.

На встрече Президента Азербайджанской Республики Гейдара Алиева с Премьер-министром Российской Федерации Виктором Черномырдиным 7 мая 1995 года в Лондоне помимо прочих вопросов, широко обсуждались трудности, вызванные в связи с закрытием из-за ситуации в Чечне всех коммуникаций в Азербайджан со стороны России. В результате этого Азербайджан оказался в условиях блокады. Стороны обменялись мнениями о полном преодолении этой проблемы. ${ }^{153}$

Глава Азербайджана Гейдар Алиев неоднократно напоминал российским властям, что в январе 1996 года в Москве было подписано соглашение о транспортировке нефти из Азербайджана по маршруту до Новороссийска. Азербайджан построил трубу на своей территории до границы, потратив 50 млн. долларов консорциума международных нефтяных компаний. Было решено подписать коммерческое соглашение тремя компаниями - российской компанией «Транснефть», Чечней и Азербайджаном. И Азербайджан согласился. ${ }^{154}$

Президент Азербайджанской Республики Гейдар Алиев на встрече с заместителем директора Федеральной пограничной службы России Александром Кожевниковым 25 января 1996 года сделал замечание, что российские СМИ пишут о переправке из Азербайджана на Северный Кавказ боевиков и оружия. Принимавший участие во встрече посол России в Баку Александр Блохин ответил, что «у него нет сведений о том, что государственные представители России обвиняют руководство Азербайджана». ${ }^{155}$ В связи с этим глава республики напомнил о заявлении генерала Барсукова в газете, «когда генерал говорит, что все идет из Азербайджана, то все думают не об отдельных людях, а в целом о стране, государстве. Поэтому нужно

\footnotetext{
${ }^{151}$ Азербайджан-Россия. Новые взаимоотномения. Новые горизонты. Баку, 2002, с 32-33.

152 Азербайджан-Россия, с.7.

153 Азербайджан-Россия, с. 167.

${ }^{154}$ Азербайджан-Россия, с.75

155 Азербайджан-Россия, с. 241.
} 
внимательно выбирать выражения». Посол России согласился с этим. ${ }^{156}$

Гейдар Алиев в интервью радиостанции «Эхо Москвы», данном им вечером 4 июля 1997 года в прямом эфире ${ }^{157}$ отверг обвинение в том, что из Азербайджана в Чечню проникали какие-то боевики. Он заметил, что на российско-азербайджанской границе множество российских пограничников, почему же они пропускали боевиков: «Почему же они пропускали? Потому что их не было, не пропускали, выдумывали все это. Вот Аслан Масхадов накануне моего приезда сюда был в Баку. Ему задавали вопрос, что в российских органах информации сообщали, что из Азербайджана идет оружие, боеприпасы и т.д. Он ответил: «Это абсолютная ложь. Мы оружие покупали у Российской армии, у российских военных частей. Там все покупалось и продавалось». Вот его слова». ${ }^{158}$

При этом Гейдар Алиев категорически отрицал слухи о готовности Азербайджана признать официально независимость Чечни. В своем ответе радиостанции «Эхо Москвы» он ясно заявил: «А что касается, вы сказали, признания Чечни, - мы таких заявлений никогда не давали. Чеченстан - это субъект Российской Федерации, и мы таких заявлений никогда не делали. И кстати, когда Аслан Масхадов был у нас в Баку, он даже такого вопроса не задавал мне. Это тоже кто-то выдумывает, распространяет». ${ }^{159}$

11 июля 1997 года Президент Азербайджана Гейдар Алиев в Баку, в Президентском Дворце принял российскую делегацию, возглавляемую первым вицепремьером Российской Федерации Борисом Немцовым. В состав делегации входили заместители секретаря Совета безопасности России Борис Березовский и Борис Агапов. В Баку прилетел и вице-премьер Чеченской Республики Ичкерия Ахмед Закаев. Гейдар Алиев назвал приезд этих гостей проявлением укрепления дружбы и сотрудничества между Азербайджаном и Россией, а также между Азербайджаном и Чеченской Республикой Ичкерия, глава которой как раз недавно побывал в Баку. Гейдар Алиев придавал большое значение необходимости поддерживать отношения с Чеченской Республикой. Он отметил совместную договоренность по задействованию нефтепровода для экспорта ранней азербайджанской нефти по северному маршруту, что является важным и отвечает интересам России, Чеченской и Азербайджанской Республик. Первый заместитель Председателя Правительства России с пониманием отнесся к этой теме и отметил подготовку проекта со стороны российской и чеченской сторон. Гейдар Алиев подчеркнул, что этот вопрос обсуждался в Москве, и он обсудил этот вопрос также с Президентом Чеченской Республики Ичкерия Асланом Масхадовым в Баку накануне визита в Москву. Гейдар Алиев напомнил, что позицию чеченской стороны поддержали, и Президент Росси Борис Ельцин и премьер-министр Виктор Черномырдин. В результате стороны согласились подписать трехстороннее соглашение между нефтяными компаниями Азербайджанской Республики, Российской Федерации и Чеченской Республики Ичкерия. Гейдар Алиев настаивал на подписании

\footnotetext{
156 Азербайджан-Россия, с. 241.

157 На радиостанции «Эхо Москвы» в прямом эфире программы ответил на вопросы Сергея Корзуна, Алексея Венедиктова и Вячеслава Терехова, начиная с 19 ч. 3 мин по московскому времени.

${ }^{158}$ Азербайджан-Россия, с. 75.

${ }^{159}$ Азербайджан-Россия, с. 75.
} 
этого документа, так как об этом говорил глава Чечни Аслан Масхадов, а Президент России Борис Ельцин и Президент Азербайджана Гейдар Алиев согласились и никаких разногласий не было. Еще в начале 1996 года Азербайджан и Россия подписали соглашение о строительстве нефтепровода через российскую территорию. Азербайджанская сторона обязательства выполнила, а российская «Транснефть» нет, что вызвало задержку с транспортировкой азербайджанской нефти. В августе 1997 года должна была начаться добыча ранней азербайджанской нефти и если российская сторона не обеспечит ее транспортировку по своей территории, то Азербайджану придется осуществлять свои обязательства по строящемуся западному нефтепроводу через Грузию, Турцию и Средиземное море.

После этого в присутствии Президента Азербайджана Гейдара Алиева состоялось подписание соглашения между Государственной нефтяной компанией Азербайджана, Министерством топлива и энергетики России и Южной нефтяной компанией Чеченской Республики Ичкерия о транзите азербайджанской нефти по нефтепроводу Баку-Грозный-Тихорецк-Новороссийск, которое подписали президент ГНКАР Натик Алиев, первый вице-премьер России Борис Немцов и президент Чеченской нефтяной компании Хожахмед Яриханов.

После завершения церемонии подписания соглашения Борис Немцов отметил значение этого документа для транспортировки азербайджанской нефти по маршруту Баку-Новороссийск. ${ }^{160}$

Б. Немцов поблагодарил представителей Чеченской Республики и Азербайджанской Республики, а также лично Президента Гейдара Алиева, благодаря которому удалось решить имевшиеся проблемы.

Хожахмед Яриханов в свою очередь отметил, что этот документ дает возможность Чеченской Республике на равных принимать участие в транзите азербайджанской нефти, а также означает конец всем рассуждениям о том, что Чечня была препятствием на пути азербайджанской нефти.

Подписание этого документа планировалось еще в 1996 году. Президент Гейдар Алиев для этого прибыл в Москву, но позиция чеченской стороны не позволила сделать это тогда. Лишь после вмешательства Гейдара Алиева в Баку состоялась церемония трехстороннего подписания соглашения. ${ }^{161}$

Гейдар Алиев в свою очередь отметил важность этого соглашения, т.к. маршрут транспортировки нефти пролегал через территорию Чеченской Республики Ичкерия. Он выразил надежду, что отныне не будет препятствий и российская компания «Транснефть» немедленно приступит к налаживанию трубопровода на территории Чеченской Республики Ичкерия в течение 20 дней как договорились. После этого станет возможным транспортировка нефти. ${ }^{162}$

Трубопровод был построен и началась транспортировка нефти. Однако события в Чечне вновь помешали этому процессу.

\footnotetext{
${ }^{160}$ Азербайджан-Россия, с. 174-175.

161 Азербайджан-Россия., с. 177.

${ }^{162}$ Азербайджан-Россия, с. 175.
} 
21сентября 1999 года Гейдар Алиев на встрече с министром топлива и энергетики Российской Федерации Виктором Калюжным заявил, что «некоторые круги, возможно, армянское лобби, возможно, какие-то реакционные круги Российской Федерации каждый раз пользуются такими случаями, чтобы осложнить отношения между Азербайджаном и Россией. Когда в Чечне шла война, в Москве без конца то по телевидению, то в газетах, то в заявлениях отдельных представителей раздавалось, что «оружие в Чечню поступает через Азербайджан из Афганистана, Пакистана, Турции, не знаю, из Ирана» или откуда-то и так далее. Все это мне надоело. И вот в январе 1996 год, когда я был в Москве, я встречался и с Борисом Николаевичем, и с Виктором Степановичем, с которым у нас потом была совместная пресс-конференция, где я четко ответил на вопросы. Никто не смог привести ни одного аргумента, подтверждающего хотя бы попустительство Азербайджана в этом вопросе. Никаких фактов нет. Я был вынужден обратиться к руководству России, сюда прибыла большая делегация пограничных войск России, они целую неделю осматривали нашу границу с Дагестаном, так как в Чечню можно пройти только через российско-азербайджанскую границу, которая проходит между Чечней и Дагестаном. Они ничего не смогли установить, найти, - никаких фактов...Я помню был как-то кризис в Первомайске между Чечней и Дагестаном. Тогда ФСБ руководил Барсуков. Он вытащил какой-то паспорт сирийца с визой о том, что он проехал туда через Азербайджан. Сколько я вам вытащу сейчас паспортов с визой через Россию, приезжающих в Азербайджан! Мы что, всех их контролируем?..». Гейдар Алиев отметил недопустимость высказывания председателя Думы Селезнева, которое просочилось в печать, что «якобы бандиты проходят через Азербайджан, перевозят оружие и так далее». Гейдар Алиев заявил, что «в Чеченстане оружие эти бандиты в основном получают от различных российских служб. И всем известно, что они и сегодня его оттуда получают». Гейдар Алиев во время этой встречи выразил четко свою позицию: «Моя позиция ясная и четкая - это позиция Азербайджанского государства. Мы всегда выступали и выступаем против сепаратизма». ${ }^{163}$

Указывая на проблему армянского терроризма, Гейдар Алиев подчеркивал: «Мы не можем, как говорят, поддерживать терроризм, не осуждать его. Я говорил и говорю - мы осуждаем все силы, независимо от того, кому они принадлежат, которые пытаются расчленить Россию. Мы всегда поддерживали и поддерживаем территориальную целостность России. ${ }^{164}$

5 ноября 1999 года Гейдар Алиев на встрече с российской правительственной делегацией, возглавляемой первым заместителем Председателя Правительства России Николаем Аксененко поднял этот вопрос. Он отметил: «Слава Богу, что мы построили нефтепровод Баку-Супса. Ведь сейчас уже консорциум добывает 5 млн тонн нефти. Что бы мы делали? Ведь это уже не азербайджанская нефть, а компаний, которые здесь работают». ${ }^{165}$ Гейдар Алиев вновь категорически отрицал связь и помощь с боевиками. По поводу ситуации в Чечне он заявил следующее: «То, что вы делаете на Северном

\footnotetext{
163 Азербайджан-Россия, с. 256-257.

${ }^{164}$ Азербайджан-Россия, с. 257.

165 Азербайджан-Россия, с. 177-178.
} 
Кавказе - это ваше внутреннее дело. Мы выступали и выступаем против терроризма. Но, что касается того, каким образом решать вопрос с Чечней, - это ваше дело. Мы всегда за политическое решение. Мы твердо стоим на этом. И, кстати, ваши руководители тоже говорят о том, что поддерживают политическое решение». ${ }^{166}$ Гейдар Алиев назвал необоснованными антиазербайджанские высказывания в российских СМИ. Николай Аксененко назвал эти СМИ «больными». ${ }^{167}$

После 2000 года в Азербайджане насчитывалось 10 тысяч чеченских беженцев. Азербайджан, несмотря на своих собственных беженцев, не мог закрыть границы для страдающих людей, оказавшихся заложниками большой политики. С 2000 года азербайджанское руководство пересмотрело свое отношение к чеченскому вопросу. Это было связано и с тем, что многие чеченские беженцы сумели улучшить свое материальное положение, найти работу, изменилась ситуация и на Северном Кавказе, постепенно восстанавливалась мирная жизнь. При этом некоторые чеченцы, проживающие в Азербайджане, стали обвиняться в незаконной деятельности. По оценке азербайджанского политолога Р. Мусабекова: «Своеобразным водоразделом стали взрывы осени 1999 года, когда чеченское сопротивление встало на путь терроризма. Общественность в Азербайджане не могла найти оправдание такого рода методам, которые и дискредитировали чеченское сопротивление». ${ }^{168}$

31 марта 2000 года на встрече с министром России по чрезвычайным ситуациям Сергеем Шойгу Гейдар Алиев выразил свою позицию так: «Россия, ведя сегодня в Чеченстане боевые действия против террористов, сепаратистов, добивается обеспечения своей территориальной целостности, что мы всегда поддерживали и поддерживаем. Так как если допускать, чтобы Россия или какая-либо другая страна растаскивалась отдельными регионами или отдельными этническими группами и так далее, то тогда постепенно разрушатся все государства. Поэтому не случайно в Хельсинском акте ОБСЕ от 1975 года зафиксирован важнейший принцип - принцип обеспечения территориальной целостности каждой страны. Поэтому вы этим занимаетесь на Северном Кавказе, в Чеченстане, и добиваетесь этого, исходя из своего права, международно-правовых норм. Мы тоже хотим пользоваться своим правом, тоже хотим, чтобы основой урегулирования этого вопроса являлись международноправовые нормы». 169

В июле 2000-го года деятельность офиса представительства Правительства Чеченской Республики Ичкерии в мусульманских странах была приостановлена. Существенную роль сыграло давление со стороны России, несколько лет не действовало железнодорожное сообщение с Россией и Волгодонской канал.

Тема стабильности в Чечне и Дагестане была поднята и 15 мая 2001 года во время приема Президентом Гейдаром Алиевым в Баку, в Президентском дворце первого заместителя министра иностранных дел России, специального представителя президента Российской Федерации по странам СНГ Вячеслава Трубникова. ${ }^{170}$

\footnotetext{
${ }^{166}$ Азербайджан-Россия, с. 179.

${ }^{167}$ Азербайджан-Россия, с. 179.

${ }^{168} \mathrm{http}: / /$ news.bakililar.az/news_sovet_chechenskix_bejencev; http://www.watchdog $(03.03 .2020)$.

169 Азербайджан-Россия, с.264.

${ }^{170}$ Азербайджан-Россия, с. 211.
} 
Отношения между азербайджанскими властями и чеченцами начали ухудшаться после выдачи Баку российским спецслужбам полевого командира Руслана Ахмадова, после визита президента России В.В. Путина в Азербайджан и событий 11 сентября 2001 года в США. ${ }^{171}$

С приходом к власти в России Владимира Путина между Азербайджаном и Россией наметилось большее взаимопонимание.

Во время официального визита Президента Российской Федерации Владимира Путина в Азербайджанскую Республику 9-10 января 2001 года Президент Азербайджана Гейдар Алиев затронул тему Чечни. На азербайджано-российских переговорах, после выступления Председателя Государственного Совета Республики Дагестан Магомедали Магомедовича Магомедова Гейдар Алиев отметил, что когда обострилась обстановка в Чечне, в Азербайджане большое беспокойство было в отношении Дагестана. ${ }^{172}$

По словам директора чеченского правозащитного центра в Баку Майрбека Тарамова, после событий 11 сентября 2001 года международные исламские фонды, действовавшие в Баку в 1999-2000 годы, под давлением США, России и Азербайджана прекратили свою деятельность и помощь чеченским беженцам. В 2001 году азербайджанские и российские спецслужбы провели совместную операцию по задержанию трех полевых чеченских командиров, прибывших в Азербайджан. Азербайджан осуждал теракты, которые по версии российской стороны, осуществляли чеченцы. Еще в марте 2001 года чеченские беженцы обратились к Президенту Азербайджана Гейдару Алиеву с открытым письмом. Чеченские беженцы не хотят возвращаться в Россию, опираясь на конвенцию 1951 года. Они сталкиваются с проблемой оформления документов, т.к. их отсылают в российское посольство. Вопрос с чеченскими беженцами Азербайджан не может решать самостоятельно и этим вопросом должно заняться Управление верховного Комиссара ООН по беженцам. Однако Управление отказалось от решения этой проблемы ввиду нежелания ни одной страны принимать чеченских беженцев. Была принята форма удостоверения УВКБ $\mathrm{OOH,} \mathrm{выданная} \mathrm{чеченским} \mathrm{беженцам} \mathrm{в} \mathrm{Азербайджане,} \mathrm{что} \mathrm{легализировало} \mathrm{их}$ нахождение только в Азербайджане, но не обеспечивало получение финансовой, гуманитарной, медицинской и иной помощи. В настоящее время в Азербайджане проживает 4930 чеченских беженцев. В последнее время они жалуются на проблемы с полицией, правом на получение метрических свидетельств детей, родившихся в Азербайджане и образование. Но чеченские беженцы в Азербайджане не теряют надежды и продолжают полностью поддерживать позиции независимого Азербайджана по всем вопросам, разделяют чувства азербайджанских беженцев и шахидов, так же, как и они пострадавших в 1990-е годы. Так, Совет чеченских беженцев выражал солидарность с народом Азербайджана и соболезнования по поводу трагедии 20 января 1990 года. «20 января в истории Кавказа навсегда останется днем потерь и обретений: умирали патриоты, и рождалась достойная Республика... У чеченцев, чувствительных к идее свободы и независимости, и несущих на этом пути огромные жертвы, есть глубоко

\footnotetext{
171 Чеченские беженцы в Азербайджане, http://www.kavkaz-uzel.eu/articles/33626/ (03.03.2020).

172 Азербайджан-Россия, с. 88.
} 
осознанное понимание того, что происходит сегодня на земле Азербайджана. Мы никогда не забудем приют чеченских беженцев на этой земле, теплоту, радушие и терпимость азербайджанского народа... Совершенный азербайджанцами подвиг был среди первых и послужил достойным примером для продолжения национальноосвободительной войны Кавказа». ${ }^{173}$

На встрече Президента Азербайджана Гейдара Алиева с российской делегацией во главе с министром внутренних дел России Борисом Грызловым 23 октября 2001 года в Баку, в Президентском Дворце, вновь звучала тема Чечни. На этот раз был затронут вопрос чеченских беженцев на территории Азербайджанской Республики.

Борис Грызлов затронул вопросы, «касающиеся и наличия российских беженцев на территории Азербайджана, в основном они являются жителями Чеченской Республики». Он заявил: «Мы допускаем, что среди них могут быть и не совсем порядочные граждане. Поэтому вопросы именно информационного обмена, вопросы, которые решают службы криминальной милиции, выходят здесь на первый план. Мы должны решать вопросы по приему этих беженцев обратно к нам, в Россию. Этот вопрос также обсуждался, и мы понимаем, что он очень серьезный и его надо решать в ближайшее время». ${ }^{174}$

Следует отметить, что азербайджанское население, несмотря на собственное непростое положение: наличие своих беженцев из-за армянской оккупации части территории страны, проявляет терпимость и дружелюбие в отношении своих северокавказских соседей, в азербайджанском обществе нет этнической дискриминации и ожесточенного отношения к другим этносам. Северокавказское население занято в торгово-посреднической и транзитной сфере через Азербайджан.

Новый виток в двусторонних отношениях начался после прихода к власти в Чечне Рамзана Кадырова. Глава Чеченской Республики Рамзан Кадыров прибыл в первый раз с официальным визитом в столицу Азербайджанскую Республику 5 января 2009 года. В ходе поездки его сопровождали Председатель Правительства ЧР Абубакар Эдельгериев, депутат Государственной думы РФ Адам Делимханов, руководитель Администрации Главы и Правительства ЧР Магомед Даудов, первый вице-премьер ЧР Иса Тумхаджиев, министр промышленности и энергетики ЧР Галас Таймасханов, министр транспорта и связи ЧР Рамзан Черхигов и другие. ${ }^{175}$

Будучи в Баку, Глава Чеченской Республики Рамзан Кадыров признался, что отношения между Чечней и Азербайджаном сводятся к челночным поездкам в Азербайджан чеченцев и присутствием в Грозном азербайджанской диаспоры. (Между тем, по нынешним сведениям Всероссийского Азербайджанского Конгресса, несмотря на то, что в Чечне живет много азербайджанцев, к сожалению, азербайджанской общины там нет. Эта важная структура отсутствует. Азербайджанские общины

\footnotetext{
173 Заур Эфендиев, Совет чеченских беженцев в Азербайджане выразил соболезнования по поводу годовщины трагедии 20 января, Bakililar.az (03.03.2020); Эльдар Исмаилзаде. Чечня через призму Карабаха// http://news.bbc.co.uk/hi/russian/russia/news; Салман Мусаев. Чеченские беженцы в Азербайджанцы// http://www.watchdog.cz/ (03.03.2020).

${ }^{174}$ Азербайджан-Россия, с. 231.

175 Рамзан Кадыров: отношения между Чеченской Республикой и Азербайджаном всегда носили дружественный характер, http://aze.az/news_ramzan_kadyirov_otnosheni_84620.html (03.03.2020).
} 
зарегистрированы во всех регионах России, кроме Чеченской Республики). ${ }^{176}$ В своем выступлении Рамзан Кадыров подчеркнул существование постоянного дружественного характера взаимоотношений чеченского и азербайджанского народов: «Мы заинтересованы в дальнейшем развитии этих отношений. Для нас интересен опыт Азербайджана в строительстве, образовании, развитии культуры и других направлений. И мы намерены подписать соглашение по этим вопросам. Я уверен, что этот визит послужит дальнейшему укреплению дружественных связей между нашими народами. У нас много проектов, которые могут заинтересовать азербайджанских инвесторов. Это также и в интересах России. Уверен, что привлечение инвесторов с дружественной для России страны Азербайджана окажет благотворное влияние на оздоровление экономического климата в целом на Кавказе», - сказал Глава ЧР. Он особо отметил необходимость развития азербайджано-чеченских отношений, перехода их на качественно новый уровень взаимовыгодного сотрудничества.

В соответствии с заранее достигнутыми договоренностями состоялось подписание соглашения о сотрудничестве между Чеченской Республикой и Азербайджанской Республикой и межправительственного соглашения.

В ходе визита состоялись встречи Главы Чеченской Республики Рамзана Кадырова с Президентом Азербайджана Ильхамом Алиевым, премьер-министром Азербайджана Артуром Расизаде, Председателем Милли Меджлиса Октаем Асадовым, а также с главой Управления мусульман Кавказа шейх-уль-исламом Аллахшюкюром Пашазаде. ${ }^{177}$

Во время встречи Президент Ильхам Алиев выразил удовлетворение участием Главы Чеченской Республики Рамзана Кадырова в проводимых в Баку мероприятиях, глава государства сказал, что его визит в Азербайджан предоставил хорошую возможность для обсуждения дальнейших перспектив двусторонних связей. Высоко оценив продолжающиеся веками дружественные отношения между азербайджанским и чеченским народами, Президент Ильхам Алиев отметил, что в Азербайджане наблюдают за восстановительной работой, реконструкцией и развитием в Чечне. Глава государства подчеркнул необходимость определения новых путей взаимодействия и развития экономических связей между Азербайджаном и Чечней. Президент Ильхам Алиев выразил уверенность в том, что под руководством Рамзана Кадырова Чечня и дальше будет успешно развиваться. ${ }^{178}$

Рамзан Кадыров напомнил, что в самые трудные для чеченцев времена Азербайджан предоставлял его соотечественникам убежище и проявлял о них высокую заботу. От своего имени и от имени чеченского народа он выразил признательность главе Азербайджанского государства, отметив, что чеченский народ этого никогда не

\footnotetext{
${ }^{176}$ Рамзан Кадыров: «К сожалению, пока все наши отношения сводятся к челночным поездкам в вашу страну наших земляков и присутствием в Грозном азербайджанской диаспоры»// http://news.day.az/politics/142525.html (03.03.2020).

${ }^{177}$ Рамзан Кадыров: отношения между Чеченской Республикой и Азербайджаном всегда носили дружественный характер, http://aze.az/news_ramzan_kadyirov_otnosheni_84620.html (03.03.2020).

178 Президент Ильхам Алиев принял Главу Чеченской Республики Рамзана Кадырова, Сайт Президента Азербайджана Ильхама Алиева. Деятельность.
} http://archive.president.az/articles.php?item_id=20091107114443889\&sec_id=10 (03.03.2020). 
забудет. ${ }^{179}$ По словам Р. Кадырова, в 2002-2003 годы в Азербайджане было примерно от 10 до 13 тыс. чеченских беженцев. В связи с нормализацией ситуации в Чечне были созданы условия для безопасного проживания граждан и возвращения их на родину. По данным Р. Кадырова, многие чеченцы вернулись в Чечню или переехали в третьи страны. ${ }^{180}$

После официального визита Главы Чеченской Республики Рамзана Кадырова началась подготовка к заключению Договора об азербайджанских инвестициях в чеченскую экономику.

Азербайджанский фонд поощрения экспорта и инвестиций (AZPROMO) 4 апреля 2012 года организовало презентацию инвестиционных проектов Чеченской Республики в Баку. В состав чеченской делегации, возглавляемой заместителем Председателя Правительства Чеченской республики, министром финансов ЧР Эли Исаевым, вошли также министр промышленности и торговли ЧР Галас Таймасханов, министр культуры ЧР Дикалу Музакаев и др. Представители Чечни встретились с членами Правительства Азербайджана и деловыми круга Азербайджанской республики. С целью налаживания взаимовыгодного экономического сотрудничества с Азербайджаном были представлены проекты по строительству предприятий по производству энергосберегающих светодиодных светильников, лесопромышленного предприятия ГУП ЧЛП «Фагус», завода по производству автомобилей и автомобильных компонентов в ЧР, Центра детского туризма и других социальных объектов. Все это вызвало заинтересованность азербайджанской стороны.

25-30 ноября 2011 года состоялся ответный визит делегации правительственных и деловых кругов, включающих 45 крупных компаний Азербайджана во главе с министром экономического развития Ш. Мустафаевым на Северный Кавказ. Делегация посетила и Чечню, где обсудили инвестиционные проекты в сфере агропромышленного комплекса, транспорта, энергетики, промышленности, туризма, спорта и культуры. Представители крупного азербайджанского бизнеса, сопровождающие Ш. Мустафаева, проявили интерес к инвестиционным проектам в области нефтепереработки, энергетики, машиностроения, агропромышленного комплекса, инфраструктуры, строительства, социальной сферы и туризма. Глава Чеченской республики заявил, что от притока инвестиций во многом зависит будущее развитие региона. «Повышение инвестиционной привлекательности республики является одной из главных задач органов исполнительной власти», - подчеркнул он. ${ }^{181}$

В письме Рамзана Кадырова Президенту Азербайджана Ильхаму Алиеву от 26 декабря 2011 года отмечалось: «Дружественный народ Азербайджана имеет многовековую традицию государственного строительства, развития науки, культуры,

\footnotetext{
${ }^{179}$ Президент Ильхам Алиев принял Главу Чеченской Республики Рамзана Кадырова// Сайт Президента Азербайджана Ильхама Алиева. Деятельность. Приемы// http://archive.president.az/articles.php?item_id=200911071144433889\&sec_id=10 (03.03.2020).

${ }_{180}$ Рамзан Кадыров: «К сожалению, пока все наши отношения сводятся к челночным поездкам в вашу страну наших земляков и присутствием в Грозном азербайджанской диаспоры»// http://news.day.az/politics/142525.html (03.03.2020).

${ }^{181}$ Чечня подпишет инвестиционный договор с Азербайджаном в начале 2012 года, http://fedpress.ru/news/polit_vlast/news_polit/chechnya-podpishet-investitsionnyi-dogovor-s-azerbaidzhanom-vnachale-2012-goda (03.03.2020).
} 
искусства, литературы. Творения азербайджанских поэтов, писателей, композиторов, художников стали достоянием всего Кавказа. Современная история республики характеризуется высокими темпами развития экономики, укрепления международного авторитета, продвижения по пути демократических реформ. Особенно приятно наблюдать за укреплением политических и экономических отношений между нашей страной - Россией и Азербайджаном. Я твердо уверен, что в рамках этого процесса есть большое будущее у взаимовыгодного сотрудничества между деловыми кругами Азербайджана и Чеченской Республики. Мы готовы в соответствии с законами Российской Федерации создать благоприятный климат для инвестиций азербайджанских фирм в перспективные проекты в нашей республике». ${ }^{182}$

Межправительственное соглашение о торгово-экономическом, научнотехническом и культурном сотрудничестве между Чеченской Республикой и Азербайджанской Республикой было подписано в ходе очередного официального визита в Азербайджан главы Чечни Рамзана Кадырова 15 ноября 2012 года. В ходе своего второго визита Рамзан Кадыров подчеркнул, что "Азербайджан - братская страна для Чеченской Республики". Он выразил надежду на дальнейшее расширение отношений между Азербайджаном и Чеченской Республикой.

Делегацию под руководством главы Чеченской Республики принял Президент Азербайджанской Республики Ильхам Алиев. ${ }^{183}$ Он выразил уверенность в том, что усиление сотрудничества между Азербайджаном и отдельными субъектами Российской Федерации будет способствовать дальнейшему укреплению также азербайджанороссийских отношений. Президент Ильхам Алиев расценил второй визит главы Чеченской Республики Российской Федерации Рамзана Кадырова в Азербайджан как хороший показатель дружественных и братских отношений, существующих между двумя народами. Президент Азербайджана отметил важность дальнейшего расширения сотрудничества в экономической, инвестиционной, гуманитарной и других сферах. В свою очередь, Рамзан Кадыров с почтением вновь вспомнил о заботе, которую общенациональный лидер азербайджанского народа Гейдар Алиев проявлял о чеченском народе в самые трудные для него времена. ${ }^{184}$

В тот же день после встречи премьер-министра Азербайджанской Республики Артура Расизаде с председателем правительства Чеченской Республики Абубакаром Эдельгериевым один на один состоялась встреча в расширенном составе с участием делегаций с обеих сторон. А. Расизаде отметил направления экономики, по которым можно наладить тесные связи и осуществлять взаимовыгодные проекты в Чеченской Республике. Председатель правительства Чеченской Республики Абубакар Эдельгериев, в свою очередь, отметил, что Чеченская Республика и Азербайджанская

182 От главы Чеченской Республики Российской Федерации Рамзана Кадырова// Сайт Президента Азербайджана Ильхама Алиева. Документы, http://ru.president.az/articles/2348 (03.03.2020).

183 Ильхам Алиев принял делегацию под руководством главы Чеченской Республики Российской Федерации Рамзана Кадырова// Сайт Президента Азербайджана Ильхама Алиева. Новости, http://ru.president.az/articles/6637 (03.03.2020).

184 Ильхам Алиев принял делегацию под руководством главы Чеченской Республики Российской Федерации Рамзана Кадырова, Сайт Президента Азербайджана Ильхама Алиева. Новости// http://ru.president.az/articles/6637 (03.03.2020). 
Республика находятся в одном регионе, и существует благоприятная среда для сотрудничества во многих сферах. "Азербайджан стремительно развивается, и Чеченская Республика хотела бы воспользоваться опытом, накопленным Азербайджаном в области социально-экономического развития. Существует большой потенциал и для развития отношений в области культуры, науки, а также в борьбе с терроризмом и экстремизмом", - подчеркнул Абубакар Эдельгериев. Затем на встрече состоялось подписание «Соглашения между правительством Азербайджанской Республики и правительством Чеченской Республики Российской Федерации о торгово-экономическом, научно-техническом сотрудничестве». Соглашение подписали премьер-министр Азербайджанской Республики Артур Расизаде и председатель правительства Чеченской Республики РФ Абубакар Эдельгериев. ${ }^{185}$

Во второй день визита официальной делегации Чеченской Республики в Азербайджан состоялась презентация инвестиционного климата, проектов и предложений Чеченской Республики. Презентация инвестиционного климата Чеченской Республики состоялась в конференц-зале отеля «HyattRegency». Для ознакомления с инвестиционным потенциалом республики пришли как представители органов государственной власти Азербайджана, так и ведущие предприниматели и бизнесмены.

Выступая перед участниками деловой встречи, заместитель Председателя Правительства ЧР, министр финансов Эли Исаев поблагодарил присутствующих за проявленный интерес к инвестиционным проектам и предложениям Чеченской Республики: «Мы благодарны руководству Азербайджана за внимание к вопросам возрождения и развития Чеченской Республики. Уверен, что при нынешнем уровне взаимоотношений мы сможем реализовать многое из задуманного и наше сотрудничество воплотится в реальные проекты, реализация которых позволит укрепить экономические связи между нашими братскими народами в перспективе по этому направлению мы возлагаем большие надежды на инвестиции... Мы ищем инвесторов и партнеров для запуска на территории республики современных производственных предприятий и предлагаем со своей стороны максимальную поддержку». Заместитель министра экономического развития Азербайджанской Республики Н. Сафаров выразил уверенность в том, что высокие темпы социальноэкономического развития Чеченской Республики делают ее весьма привлекательным регионом для инвесторов.

Министр экономического развития и торговли ЧР Абдула Магомадов более детально рассказал о восстановлении республики, предпринимаемых шагах по активному развитию всех отраслей экономики республики. Он отметил, что «экономика Чеченской Республики выходит на инвестиционный этап своего развития, так как обеспечить экономический рост, необходимый для решения актуальных социальных, экономических и экологических проблем, невозможно без притока инвестиций. В рамках активизации инвестиционной деятельности в республике сформирован портфель из 75 инвестиционных проектов. Все они предусматривают

\footnotetext{
185 Рамзан Кадыров прибыл в Баку, Газета «Эхо», Общественно-политическая газета, 6 Мая 2016, № 81 (3720)
} 
реконструкцию существующих или строительство новых, современных высокотехнологичных производств. Все проекты имеют бизнес-планы и разработанную консалтинговой компанией проектно-сметную документацию». Об итогах и перспективах развития промышленности и энергетики республики рассказал министр промышленности и энергетики ЧР Галас Таймасханов. По окончании выступлений докладчиков состоялась презентация для представителей бизнес-структур Азербайджана отдельных проектов, в том числе по автомобилестроению и производству автомобильных компонентов, строительству деревообрабатывающего завода «Фагус», производству светодиодных осветительных приборов и т.д. До начала презентации участникам деловой встречи был продемонстрирован ролик о возрождении и развитии республики для того, чтобы они четче представляли себе современную Чеченскую Республику и открывающиеся возможности ведения бизнеса.

По завершении презентации участники в неформальной обстановке обсудили детали отдельных проектов и предложений, обменялись контактами и наметили план дальнейшего сотрудничества.

Ранее в этот же день состоялась встреча представителей Чеченской Республики с министром культуры и туризма Азербайджана А. Караевым и заместителем министра энергетики и промышленности Азербайджана Н. Аббасовым. В ходе двухсторонних встреч стороны более предметно обсудили перспективы сотрудничества в каждой отрасли.

Вечером того же дня члены делегации Чеченской Республики посетили завод по производству газобетона «ААС». Этот современный завод введен в эксплуатацию около 4 месяцев назад и по своим характеристикам не имеет аналогов в Закавказье. По словам генерального директора завода Теймура Абдураимова, производственная мощность завода составляет 600 куб. м. готовой продукции в сутки. На предприятии в 4 смены работают около 150 работников, включая сотрудников администрации. Завод построен на частные инвестиции и оборудован современным автоматизированным оборудованием. ${ }^{186}$

Чеченская республика РФ готова сотрудничать с Азербайджаном в сфере нефтедобычи, сказал журналистам в среду в Баку заместитель премьер-министра Чечни, министр финансов Эли Исаев. "Сегодня лицензию на добычу нефти в Чечне имеет нефтяная компания "Роснефть". Лицензия была выдана в 2002 году на 20 лет. Тем не менее, эта отрасль у нас продолжает изучаться. В Чечне имеется ряд нефтяных месторождений, где необходимо провести геологоразведочные работы. В этом направлении возможно сотрудничество с Азербайджаном", - сказал Исаев. По его словам, чеченская делегация прибыла в Азербайджан с рядом инвестиционных проектов в таких секторах, как транспорт, энергетика, строительство, сельское хозяйство и другие. "Рынок Чеченской республики еще не освоен, но обладает большим потенциалом. По всем показателям экономического роста за последнее время Чечня опережает другие субъекты Российской Федерации. Это делает Чечню

\footnotetext{
186 Сайд-Эми Хасиев, Азербайджано-чеченская деловая встреча, «Вести Республики». Общественнополитическая газета Чеченской Республики, http://vesti95.ru/61553/ (03.03.2020).
} 
привлекательной для инвестиций, и мы надеемся на сотрудничество с Азербайджаном в этой сфере", - подчеркнул Исаев. ${ }^{187}$

Визит Кадырова в Азербайджан внесет вклад в давние дружественные связи между двумя странами, сказал встрече спикер Милли Меджлиса Азербайджана Октай Асадов. Он также выразил надежду на дальнейшее развитие экономических связей.

В ходе поездки состоялась также встреча Р. Кадырова с Председателем Управления мусульман Кавказа шейхом-уль-исламом Аллахшукюром Пашазаде, в ходе которой была подчеркнута необходимость и дальше поддерживать тесные контакты между учеными-алимами Чечни и Азербайджана, совместно и активно бороться с терроризмом, экстремизмом на Кавказе, согласованными усилиями духовных управлений разрешать межконфессиональные, межнациональные проблемы, проводить обдуманную и целеустремленную работу среди молодежи, женщин и всего населения по разъяснению основ Ислама, содержания шариата. Глава Чечни поблагодарил шейхауль-ислама Аллахшукюра Пашазаде за деятельность в Консультативном Совете стран СНГ. ${ }^{188}$

Надо отметить, что Духовное Управление мусульман Кавказа под председательством шейха-уль-ислама Аллахшукюра Пашазаде и Духовное управление мусульман Чеченской Республики под председательством главы Духовного управления мусульман Чеченской Республики муфтия Салаха Межиева проводят регулярные встречи и консультации. Председатель Управления мусульман Кавказа шейх уль-ислам Аллахшукюр Пашазаде был, в частности, в числе 800 гостей, прибывших в Грозный из регионов России и зарубежных стран, для участия на торжественной церемонии, посвященной инаугурации Рамзана Кадырова 3 апреля 2011 года. ${ }^{189}$ В конце августа 2012 года шейх-уль-ислам Аллахшукюр Пашазаде, находясь с визитом в Чечне, на торжественном заседании, посвященном десятилетию Совета по хаджу и Хадж-миссии в России, назвал Чечню одним из нравственных центров Кавказа. За выдающиеся заслуги в религиозной деятельности по укреплению исламского наследия и сохранения духовного единства мусульман Шейх-уль-ислам Аллахшукюр Пашазаде был награжден юбилейной медалью к 60-летию первого Президента ЧР Ахмата-Хаджи Кадырова. ${ }^{190}$ В конце мая 2014 года шейх уль-ислам Аллахшукюр Пашазаде участвовал на VI Международном миротворческом форуме "Ислам - религия мира и созидания", состоявшемся в городе Грозном и побывал в школе хафизов имени Шейха Заеда бен Султана Аль Нахайана в Гудермесе. ${ }^{191}$

Из года в год Чеченская Республика набирает силу и процветает, это может подтвердить любой человек, проезжающий по республике. Отрадно отметить, что глава

\footnotetext{
187 Чечня готова сотрудничать с Азербайджаном в нефтяной сфере, http://www.memo.ru/d/115634.html (03.03.2020).

188 Муфтий ЧР C-X. Мирзаев - об итогах поездки делегации Чечни в Азербайджан, http://serdcechechni.ru/index.php/template/islam/item (03.03.2020).

189 В Грозном состоялась инаугурация Главы Чеченской Республики Рамзана Кадырова, http://www.chechnya.gov.ru/page.php?r=126\&id=9105 (03.03.2020).

${ }^{190}$ Шейхульислам Аллахшукюр Пашазаде находится с визитом в Чечне// http://www.anspress.com/heyatterzi/30-08-2012/sheyhulislam-allahshukyur-pashazade-nahoditsya-s-vizitom-v-chechne-video (03.03.2020).

${ }^{191} \mathrm{VI}$ Международный миротворческий форум «Ислам созидания»// http://islamdag.ru/analitika/15028 (03.03.2020).
} 
ЧР Рамзан Кадыров, продолжая курс Первого Президента ЧР, Героя России АхматаХаджи Кадырова, много делает во благо не только своей республики, но и всего Северного Кавказа. Его стремление установить полный контроль над предприятием «Чеченнефтехимпром» связано с интересами Чеченской Республики и в этом плане при установлении полного контроля над добычей нефти важно привлечение иностранных инвестиций.

Как и в XIX веке большое значение могло бы иметь экономическое сотрудничество с Азербайджаном в нефтяной сфере. История нефтяного дела и нефтяной промышленности в Азербайджане и Чечне тесно переплетена еще со второй половины XIX - начала XX вв. ${ }^{192}$ В начале XX века после распада Российской империи, а затем после распада Советского Союза в 1991 году стремление Азербайджана вернуть контроль над нефтересурсами было продиктовано стремлением к самостоятельному управлению во имя блага и процветания своей страны и народа.

В настоящее время азербайджанцы и чеченцы связаны религиозными, культурными узами. Тесный контакт между спортсменами двух субъектов. Азербайджанцы осуществляют частные мелкие инвестиции в экономику Чечни. 80\% ресторанного бизнеса и торговый рынок Чечни находится в руках азербайджанцев. Азербайджанские и чеченские предприниматели взаимодействуют в осуществлении поставок зерна, сгущенного молока и масла, торговле металлом, и в разных сферах частного бизнеса.

Азербайджанцы принимали участие в строительных работах в Чечне, в том числе в возведении комплекса высотных зданий в центре столицы Чечни города Грозного на берегу реки Сунжа, по проспекту имени А-Х. Кадырова, "Грозный-Сити". Застройкой занимались строительные фирмы, в т.ч. "Пента". Компания Penta (директор гражданин Азербайджана Сиявуш Джаваншир Мамедзаде удостоен звания «Почетный строитель Чеченской Республики) для возведения самых крупных и дорогостоящих объектов в Чечне: жилой комплекс в городе Аргуне, зона реабилитации на берегу реки Аргун длиной 1 км, медресе в Гудермесе, городская аргунская больница, - привлекла свыше 4 тыс. граждан из Азербайджана и стран Малой и Средней Азии.

Стоит отметить, что по сведениям самих чеченцев Баку, в столице Азербайджана проживает 3-5 тыс. чеченцев. Почти все они являются гражданами Российской Федерации. При этом, живут, учатся, работают и прекрасно себя чувствуют в Баку. У них нет проблем с толерантным и близким по культуре азербайджанским народом.

Упрочению азербайджано-чеченских связей и налаживанию взаимопонимания могло бы способствовать формирование азербайджанской общины в Чечне и чеченской общины в Азербайджане.

Чеченцы долгое время пытаются зарегистрироваться в Азербайджанской Республике как беженцы. Этот статус позволил бы им не возвращаться на историческую родину и перебраться далее в развитые страны Европы. По мнению руководителя чеченской общины в Азербайджане Рамзана Моллаева, изложенному в

192 Севиндж Алиева, Азербайджан в экономической жизни народов Северного Кавказа (нефтяная промышленность: зарождение, развитие и трансформация), Современная научная мысль. Научный журнал НИИ истории, экономики и права, Москва: НИИ ИЭП, 2013. № 2, с.25-36. 
СМИ, в 2000 году в Азербайджане было 15 тыс. чеченцев, на лето 2015 года в Азербайджане осталось 521 чеченцев, взятых под юрисдикцию ООН. ${ }^{193}$ По сведениям Моллаева, в 2016 году в Азербайджане проживало 553, в 2017 году - 461 чеченский беженец. Наряду с ними в Азербайджане проживают еще и чеченцы, не имеющие указанного статуса. ${ }^{194}$

Глава Чеченской Республики Рамзан Кадыров 29 апреля 2016 года назначил новым министром здравоохранения Чечни азербайджанца Эльхана Сулейманова, главного врача Республиканского онкологического диспансера. Новому министру поручено провести коренную реорганизацию в Минздраве, лечебных учреждениях Грозного, районов и населенных пунктов.

Эльхан Сулейманов получил образование в Азербайджанском медицинском университете (диплом с отличием), после учебы работал в Бакинском онкологическом научном центре Азербайджана. В Москве окончил аспирантуру на базе Российского Онкологического Центра им. Н.Н. Блохина, является кандидатом медицинских наук. Проходил стажировку в США и Германии. По приглашению Рамзана Кадырова переехал из Москвы в Грозный в апреле 2014 года, возглавил республиканский онкодиспансер и одновременно выполнял обязанности советника Главы Республики по вопросам здравоохранения.

23 - 25 мая 2016 года с визитом в Грозном находился Руководитель Администрации Президента Азербайджана Рамиз Мехтиев. Он участвовал в VII международной встрече высоких представителей, курирующих вопросы безопасности. Рамиз Мехтиев провел встречу с Секретарем Совета Безопасности Российской Федерации Н.П. Патрушевым. ${ }^{195}$ В стратегии региональной безопасности азербайджанские власти придерживаются позиции многоуровненности и уравновешенности внешней политики.

24 мая 2016 года в Грозный прибыла делегация правительства Азербайджанской Республики во главе с руководителем администрации президента Азербайджана Рамизом Мехтиевым для участия в Международном форуме по вопросам безопасности. На встрече с Рамзаном Кадыровым Рамиз Мехтиев подчеркнул: «Вы являетесь истинным сыном чеченского народа. Вам удалось дать чеченскому народу счастливую жизнь, преодолеть сложности и проблемы, которые, мы это знаем по истории, были здесь совсем недавно. Некогда разрушенный Грозный стал прекрасным городом, одним из лучших в России. Вы являетесь не только подлинным сыном чеченского народа, но и сыном своего отца, воплощаете в жизнь его мечты. Азербайджанский народ всегда рядом с чеченским народом». Кадыров в свою очередь признался: «Мы всегда были союзниками, были вместе. Укрепление связей Азербайджана с Россией — это важное и

\footnotetext{
${ }^{193}$ В Баку осталось всего 500 чеченцев, https://haqqin.az/news/57438 (03.03.2020).

194 За десять последних лет число чеченских беженцев в Азербайджане уменьшилось в десять раз, но никто из них не хочет возвращаться на родину, https://ru.sputnik.az/life/20170917/411886832/pereseleniechechencev-baku-v-turciju.html (03.03.2020).

195 Азербайджанская делегация приняла участие в международной встрече высоких представителей, курирующих вопросы безопасности, http://www.1news.az/mobile/news/azerbaydzhanskaya-delegaciyaprinyala-uchastie-v-mezhdunarodnoy-vstreche-vysokih-predstaviteley-kuriruyuschih-voprosy-bezopasnosti (03.03.2020).
} 
нужное направление. Я уверен, что мы должны быть вместе, вместе защищать наши народы и страны, чтобы врагу даже в голову не могло прийти попытаться с нами заигрывать».

Рамзан Кадыров также выразил признательность Рамизу Мехтиеву за помощь, которую Азербайджан оказал чеченцам в период военных кампаний: «Как мы помним, тогда всех чеченцев сделали бандитами, террористами, с нами никто не хотел общаться, тем более принимать беженцев. Я был на встрече Ахмата-хаджи с Гейдаром Алиевым. Он очень хорошо относился к чеченскому народу, помогал. Мы об этом никогда не забудем и будем ценить».

Взаимоотношения Азербайджана и Чечни в 1990 годы строились по принципу, озвученному Гейдаром Алиевым: самоопределение Чечни - это проблема России, а чеченский вопрос - дело самих чеченцев, к которому Азербайджан не имеет права быть безучастным.

В интервью дагестанского общественного деятеля Магомеда Чагучиева, проректора по международным делам Московского независимого экологополитологического университета (МНЭПУ) для EADaily, муфтий Чечни Ахмат Кадыров попросил его помочь встретиться с начальником Генерального штаба Вооруженных сил России Анатолием Квашниным: «Я согласился, мы вместе поехали в Генштаб, на Арбатскую. Считаю, что тогда, в 1997 году, Ахмат Кадыров, в то время муфтий „Ичкерии“, полевой командир, сделал шаг в сторону России. Полагаю, за этим шагом мог стоять президент Азербайджана Гейдар Алиев». ${ }^{196}$

Резюмируя вышесказанное, отметим, что в Азербайджане делается все возможное для здорового общежития всех без исключения национальных меньшинств. Отношение к мужественному и бесстрашному чеченскому народу - особенно трепетное.

Азербайджано-чеченские отношения имеют большой запас прочности и все перспективы для эффективного сотрудничества в экономической, социальной, научной и культурной сферах как на самом высоком государственном, так и на частном уровнях.

Таким образом, в советское время межэтнические связи между азербайджанцами и чеченцами стали развиваться и укрепляться в новом ракурсе, трудовое распределение и миграции приобрели запланированный государством характер. Развитие науки и культуры, проведение общесоюзных мероприятий способствовали улучшению взаимопониманию. В условиях распространения идеи интернационализма и братства народов ширились культурные связи. На современном этапе, когда Азербайджан независимое светское демократическое государство, а Чечня - наиболее значимая на Северном Кавказе республика, развитие межрегиональных экономических и культурных связей имеет огромное значение для укрепления стабильности и безопасности всего региона.

\footnotetext{
196 Мехтиев - Кадырову: «Азербайджанский народ всегда рядом с чеченским народом», https:/eadaily.com/ru/news/2016/05/25/mehtiev-kadyrovu-azerbaydzhanskiy-narod-vsegda-ryadom-schechenskim-narodom (03.03.2020).
} 


\section{Streszczenie:}

Artykuł poświęcony jest rozwojowi stosunków azerbejdżańsko-północnokaukaskich na przykładzie Czeczenii w XX-XXI wieku. Autor zidentyfikował kilka etapów. Pierwszym z nich był okres 1917-1920, kiedy to po proklamowaniu władzy bolszewickiej w Azerbejdżanie i na Kaukazie Północnym rozpoczął się ruch społeczno-polityczno-wyzwoleńczy, rozpoczął się proces poszukiwania form samodzielnej egzystencji. Drugi to okres sowiecki, kiedy w ramach jednego państwa rozwinęły się więzi społeczno-gospodarcze i kulturowe. Trzeci jest nowoczesny, kiedy po upadku ZSRR Azerbejdżan odzyskał niepodległość, a naród czeczeński wyróżniał się jako niezależna jednostka administracyjna i otrzymał status republiki.

\section{Słowa kluczowe:}

Azerbejdżan, Czeczenia, ZSRR, nacjonalizm, represje, deportacje, niepodległość, ropa naftowa.

\section{Key words:}

Azerbaijan, Chechnya, USSR, nationalism, repression, deportation, independence, oil.

\section{Bibliografia:}

1. VI Международный миротворческий форум «Ислам - религия мира и созидания», https://azertag.az/ru/xeber/Islam__religiya_mira_i_sozidaniya-121576 (03.03.2020).

2. В.А. Авксентьев, Этническая конфликтология. Ч.2, Ставрополь 1996.

3. Азербайджан-Россия. Новые взаимоотношения. Новые горизонты, Баку 2002.

4. Азербайджанская делегация приняла участие в международной встрече высоких представителей, курирующих вопросы безопасности, http://www.1news.az/mobile/news/azerbaydzhanskaya-delegaciya-prinyala-uchastiev-mezhdunarodnoy-vstreche-vysokih-predstaviteley-kuriruyuschih-voprosybezopasnosti (03.03.2020)

5. В.С. Белозеров, Этническая карта Северного Кавказа, Москва 2005.

6. В Баку осталось всего 500 чеченцев, https://haqqin.az/news/57438

7. В Грозном состоялась инаугурация Главы Чеченской Республики Рамзана Кадырова// http://www.chechnya.gov.ru/page.php?r=126\&id=9105, https://www.grozny-inform.ru/news/politic/24406/ (03.03.2020).

8. За десять последних лет число чеченских беженцев в Азербайджане уменьшилось в десять раз, но никто из них не хочет возвращаться на родину, https://ru.sputnik.az/life/20170917/411886832/pereselenie-chechencev-baku-vturciju.html (03.03.2020)

9. Заур Эфендиев, Совет чеченских беженцев в Азербайджане выразил соболезнования по поводу годовщины трагедии 20 января, Bakililar.az (03.03.2020).

10. Ильхам Алиев принял делегацию под руководством главы Чеченской Республики Российской Федерации Рамзана Кадырова, Сайт Президента 
Азербайджана Ильхама Алиева. Новости, http://ru.president.az/articles/6637 (03.03.2020).

11. Эльдар Исмаилов, Власть и народ. Послевоенный сталинизм в Азербайджане, Баку: Изд-во Адильоглу 2003.

12. Коллективизация и антиколхозные выступления в Дагестане (1927 - 1940). Документы и материалы, Махачкала 2007.

13. Д.Б. Малышева, Пределы влияния России в Закавказье, Южный фланг СНГ. Центральная Азия - Каспий - Кавказ: энергетика и политика, Москва 2006.

14. Мехтиев - Кадырову: «Азербайджанский народ всегда рядом с чеченским народом»// https://eadaily.com/ru/news/2016/05/25/mehtiev-kadyrovuazerbaydzhanskiy-narod-vsegda-ryadom-s-chechenskim-narodom (03.03.2020).

15. Муфтий ЧР C-Х. Мирзаев - об итогах поездки делегации Чечни в Азербайджан, http://serdce-chechni.ru/index.php/template/islam/item (03.03.2020).

16. От главы Чеченской Республики Российской Федерации Рамзана Кадырова, Сайт Президента Азербайджана Ильхама Алиева. Документы, http://ru.president.az/articles/2348 (03.03.2020).

17. Президент Ильхам Алиев принял Главу Чеченской Республики Рамзана Кадырова, Сайт Президента Азербайджана Ильхама Алиева. Деятельность. Приемы, http://archive.president.az/articles.php?item_id=20091107114443889\&sec_id=10 (03.03.2020).

18. Рамзан Кадыров прибыл в Баку, Газета «Эхо», Общественно-политическая газета, 6 Мая 2016, № 81 (3720).

19. Рамзан Кадыров: «К сожалению, пока все наши отношения сводятся к челночным поездкам в вашу страну наших земляков и присутствием в Грозном азербайджанской диаспоры», http://news.day.az/politics/142525.html (03.03.2020).

20. Рамзан Кадыров: отношения между Чеченской Республикой и Азербайджаном всегда носили дружественный характер, http://aze.az/news_ramzan_kadyirov_otnosheni_84620.html (03.03.2020).

21. Д.Романов, Ю. Финк, Потенциальные очаги этнических конфликтов на Северном Кавказе (по материалам СМИ), Этнические процессы современности, Ставрополь 1996.

22. Сайд-Эми Хасиев, Азербайджано-чеченская деловая встреча, «Вести Республики». Общественно-политическая газета Чеченской Республики, http://vesti95.ru/61553/ (03.03.2020).

23. Салман Мусаев, Чеченские беженцы в Азербайджанцы, http://www.watchdog.cz/ (03.03.2020).

24. Севиндж Алиева, Азербайджан в экономической жизни народов Северного Кавказа (нефтяная промышленность: зарождение, развитие и трансформация), Современная научная мысль. Научный журнал НИИ истории, экономики и права, Москва: НИИ ИЭП, 2013. № 2, с.25-36.

25. Севиндж Алиева, Старые и новые очертания азербайджано-чеченских отношений// http://www.turkishnews.com/ru/content/2012/11/19 (03.03.2020).

26. Чечня готова сотрудничать с Азербайджаном в нефтяной cфepe// http://www.memo.ru/d/115634.html (03.03.2020).

27. Чечня подпишет инвестиционный договор с Азербайджаном в начале 2012 года// http://fedpress.ru/news/polit_vlast/news_polit/chechnya-podpishetinvestitsionnyi-dogovor-s-azerbaidzhanom-v-nachale-2012-goda (03.03.2020). 
28. Шейхульислам Аллахшукюр Пашазаде находится с визитом в Чечне// http://www.anspress.com/heyat-terzi/30-08-2012/sheyhulislam-allahshukyurpashazade-nahoditsya-s-vizitom-v-chechne-video (03.03.2020).

29. Эльдар Исмаилзаде, Чечня через призму Карабаха// http://news.bbc.co.uk/hi/russian/russia/news $\quad$ (03.03.2020) 
